\title{
A Survey on Occurrence and Diversity of Insect Pests of Cauliflower in Dindigul and Theni Districts of Tamil Nadu, India
}

\author{
Arun Debbarma $^{1^{*}}$, J. Jayaraj ${ }^{1}$, P. Chandramani ${ }^{2}$, N. Senthil ${ }^{3}$, \\ M. Ananthan ${ }^{4}$ and K. Prabakaran ${ }^{5}$ \\ ${ }^{1}$ Department of Entomology, AC \& RI, Madurai, Tamil Nadu, India \\ ${ }^{2}$ Department of Entomology, AC \& RI, Kudumiyanmalai, Tamil Nadu, India \\ ${ }^{3}$ Department of Biotechnology, AC \& RI, Madurai, Tamil Nadu, India \\ ${ }^{4}$ Department of Horticulture, Horticultural Research Station, Thadiyankudisai, Tamil Nadu, India \\ ${ }^{5}$ Department of Agricultural Economics, AC \& RI, Madurai, Tamil Nadu, India \\ *Corresponding author
}

\section{A B S T R A C T}

\begin{tabular}{|l|}
\hline Key w or d s \\
Survey, \\
Cauliflower, Pests, \\
Natural enemies. \\
\hline Article Info \\
\hline Accepted: \\
26 August 2017 \\
Available Online: \\
10 September 2017
\end{tabular}

Roving surveys were taken from September 2015 to 2017 covering Theni and Dindigul districts of Tamil Nadu, India aiming to document the occurrence of major insect pests and their natural enemies in cauliflower crop at different elevations. The insect pest diversity of cauliflower was from Lepidoptera (29.63 per cent), Homoptera (14.81 per cent), Orthoptera (14.81 per cent), Hemiptera (7.81 per cent), Coleoptera (7.41 per cent), Diptera (7.41 per cent), Hymenoptera (3.70 per cent), Thysanoptera (3.70 per cent), Dermaptera (3.70 per cent), Dictyoptera (3.70 per cent) and Acarina (3.70 per cent) respectively. The natural enemies diversity were from Hymenoptera (41.67 per cent), Coleoptera (20.83 per cent), Hemiptera (12. 50 per cent), Diptera (8.33 per cent), Neuroptera (4.17 per cent), Odonata (4.17 per cent) and Araneae ( 8.33 per cent). The most damaged plant parts were curds followed by leaves and stem.

\section{Introduction}

Cauliflower (Brassica oleracea var. botrytis Linn.) is one of the most important cruciferous vegetables in India and worldwide however the production is low because this crop suffers from both the biotic and abiotic stresses. In India, cauliflower crop occupies an area of 433.9 ha with a production of 8573.3 MT (National Horticulture Board, 2015) and this is one of the most ravaged cruciferous vegetables by insect pests. Earlier in India, 37 insects' pests were recorded in cabbage, Lal, (1975), and Bhatia and Verma, (1993). Raja et al., (2014) recorded 11 insect pests in Tamil Nadu in crucifers and Raju and Sivaprakasagam, (1989) reported Diamondback moth, Plutella xylostella (Linnaeus), Mustard aphid, Lipaphis erysimi (Kaltenbach), cabbage semilooper, Trichoplusiani (Hubner), and cutworms, Agrotis ipsylon (Hubner), as widespread pests on crucifers. Worldwide surveys indicate the major pests that ravaged the Brassicaceae 
family were viz., diamondback moth, Plutella xylostella (Linnaeus), cabbage leaf webber, Crocidolomia binotalis (Zeller), Gram pod borer, Helicoverpa armigera (Hubner), tobacco caterpillar, Spodoptura litura (Fabricius), cabbage semilooper, Trichoplusiani (Hubner), cabbage Head borer, Hellulaundalis (Fabricius), cabbage butterfly, Pierisbrassicae (Linnaeus), cutworms, Agrotis ipsylon (Hubner), cabbage aphid, Brevicoryne brassicae (Linnaeus), mustard aphid, Lipaphis erysimi (Kaltenbach), green peach aphid, Myzuspersicae (Sulzer), Flea beetle, Phyllotretacruciferae (Goeze), painted bug, Bagrada cruciferarum (Kirkaldy), mustard sawfly, Athalialugens proxima (Klug) (Bonneimaison, 1965, Lu, 1983, Cheng et al., 1987, Anita and Suchi, 2012, Singh and Pal, 2014, Deeplata and Rao, 2012, Ratnasri, 2012, Palande et al., 2004.

\section{Materials and Methods}

Roving Surveys were carried out in different cauliflower growing areas of Dindigul $\left(10.365581^{\circ} \mathrm{N}\right.$ and $\left.77.970657^{\circ} \mathrm{E}\right)$ and Theni $\left(10.008834^{\circ} \mathrm{N}\right.$ and $\left.77.4923747^{\circ} \mathrm{E}\right)$ districts during 2015-2017 to investigate the occurrence and diversity of major insect pests and their natural enemies. The surveywas conducted in Komalipatty, Kannanur, Kodaikanal, Kallymandayam, Amblikkai, Thangachiyamapatty, Virupachi, Oddanchatrum, Odaipatty, Lakyankottaiof Dindigul district and also survey was conducted in Kottur, Veerapandi, Kumbum, Andipatty, Chinnamanur, Merkayankottai and Ayyamapatty of Theni district. The surveys were carried out in three elevations viz., $150 \mathrm{~m}$ MSL, 500m MSL and above $1500 \mathrm{~m}$ MSL. Farmers' fields having at least 0.5 acre area was selected and the field was divided into five plots $\left(\mathrm{P}_{1}, \mathrm{P}_{2}, \mathrm{P}_{3}, \mathrm{P}_{4}\right.$ and $\left.\mathrm{P}_{5}\right)$ and in each plot 10 plants were selected at random for counting the pests population and observations were taken in zigzag rows (Raja et al., 2014). Sampling population densities of various stages viz., eggs, larvae/nymph, pupae and adult of the pest were observed once in 15 days by following the method of Muhammad Haseeb et al., (2001). These pests and natural enemies were identified based on the taxonomic keys. The individual species was recorded in accordance with family. The following formula were used to find out the individual species per cent, overall order per cent and plant parts damaged per cent.

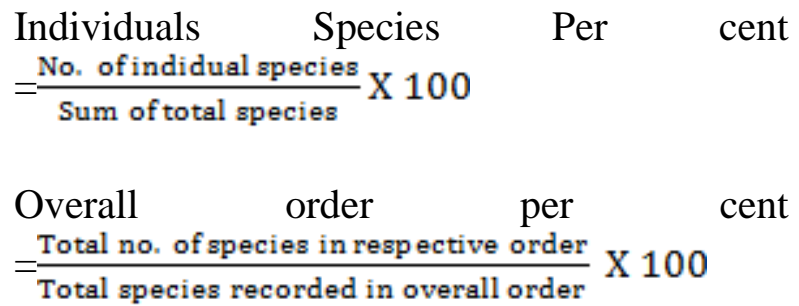

Plant parts damaged diversity per cent $=$ $\frac{\text { Pestfeedingonnespective plant parts }}{\text { TotalNo.of Speciesfeedingonwholeplant }} X 100$

\section{Results and Discussion}

The survey indicated that in Theni as well as in Dindigul districts, the Diamondback moth, Plutellaxylostella (Linnaeus) was most prevalent pest on cauliflower (Table 1). The others pests recorded during the survey were viz., tobacco caterpillar, Spodopturalitura (Fabricius), cabbage leaf webber, Crocidolomia binotalis (Zeller), cabbage semilooper, Trichoplusiani (Hubner), cabbage Head borer, Hellulaundalis (Fabricius), Gram pod borer, Helicoverpa armigera (Hubner), cutworms, Agrotisipsylon (Hubner), Bihar hairy caterpillar, Spilosomaobliqua (Walker), painted bug, Bagradacruciferarum (Kirkaldy), Sugarcane pyrilla, Pyrilla perpusilla (Walker), Mustard Aphid, Lipaphiserysimi (Kaltenbach), Green peach Aphid, Myzus persicae (Sulzer), Cabbage Aphid, Brevicorynebrassicae (Linnaeus), whitefly, Bemisia tabaci (Gennadius), cabbage flea beetle, Phyllotreta cruciferae (Goeze), ash weevil, Myllocerusspp, earwigs, Forficula auricularia (Linnaeus), cabbage 
root borer, Delia radicum (Linnaeus), leaf miner, Chromatomyia horticola (Goureau), shorthorned grasshopper, Oxyaspp, grasshopper, Atractomorpha crenulata (Fabricius), cricket, Gryllus campestris (Linnaeus), katydid, Pterophilla camellifolia (Fabricius), thrips, Thrips tabaci (Lindeman), American cockroach, Periplaneta americana (Linnaeus), mustard sawfly, Athalialugens proxima (Klug) and mites (Table 1 and Fig. 1). Variance of these pests from season to season and region to region is comparable with the findings of Sachan and Srivastava, (1972), Sachan and Gangwar (1990) and Chaudhuri et al., (2001), Sarfarazet al., (2005).

The predator noticed and recorded during the survey were coccinellids viz., Chilomenessexmaculatus (Fabricius), Coccinella septumpunctata (Fabricius), Brumoides suturalis (Fabricius)and Scymnus sp., syrphids such as Episyrphus balteatus (Fabricius) and Ischiodons cutellaris (Fabricius), predatory bug such as big eye bug, Geocoris spp, pirate bug, Orius insidiodus (Say) and Damsel bug, Nabisroseipennis (Reuter). The others predators recorded during the survey were green lacewing, Chrysoper lazastrowi (Sillemi), ants such as big headed ants, Pheidole sp. (Fabricius), Solenopsi sinvicta (Boren) and, carpenter ants, Componatus compressus (Fabricius), the spider such as the jumping spider and wolf spider (Table 2 and Fig. 2). Predators recorded during the survey in cruciferous crop were comparable with the findings of several authors (Firakeet al., 2012, Jalali et al., 2003, Agarwal et al., 2007, Sood, 2004). The ground skimmer, Diplacodes trivialis (Rambur) was noticed and recorded feeding on adult diamondback moth, Plutella xylostella (Linnaeus) during the survey periods in both Theni and Dindigul districts as efficient predators.

The parasitoids noticed during the survey were viz., Cotesia plutellae Kurdjumov,
Diadegmasemiclausum Kurdjumov, Oomyzus sokolowski (Kurdjumov), Diadromus spp, Trichogramma spp, Diaretiellarapae M'Intosh, Aphidius spp., and Encarsia Formosa (Gahan) (table 2 and Fig. 2). These parasitoids recorded in present survey conducted in Theni and Dindigul Districts in crucifers crops were in conformity with the finding of Chandramohan, (1994) and Ushachauhan et al., (1997).

The survey was carried out in 150, 500 and $1500 \mathrm{~m}$ MSL of Dindigul district and $150 \mathrm{~m}$ MSL of Theni District. The insect pests as well as natural enemies population diversity varies according to the elevations. The most prevalent pests order were from Lepidoptera, Homoptera, Orthoptera, Hemiptera, Coleoptera, Diptera, Hymenoptera, Thysanoptera, Dermaptera, Dictyoptera and Acarina respectively (Table 3). The natural enemies diversity order were from Hymenoptera (41.67 per cent), Coleoptera (20.83 per cent), Hemiptera (12. 50 per cent), Diptera (8.33 per cent), Neuroptera (4.17 per cent), Odonata (4.17 per cent) and Araneae (8.33 per cent) (Table 4$)$.

The most preferred and susceptible cauliflower plant part damaged were curds (27.59 per cent) followed by leaves by sucking ( 24.14 per cent), leaves by defoliation (13.79 per cent), leaves by marginal feeding (10.34 per cent), whereas leaves by webbing, leaves by zigzag mines, roots and stem, leaf mining or circular hole and leaves by circular minute holes share same per cent of damaged such as 3.45 per cent respectively (table 5). The order Lepidoptera were most consistent in ravaging this crop followed by Homoptera, Hemiptera, Orthoptera, Coleoptera, Diptera, Dermaptera, Hymenoptera, Thysanoptera, Dictyoptera and Acarina. The variation of feeding was noticed among different species of the insect pests on cauliflower and these pests infestation also varies with different crop growth stages. 
Fig.1 Map of survey areas viz., Theni and Dindigul Districts of Tamil Nadu, India

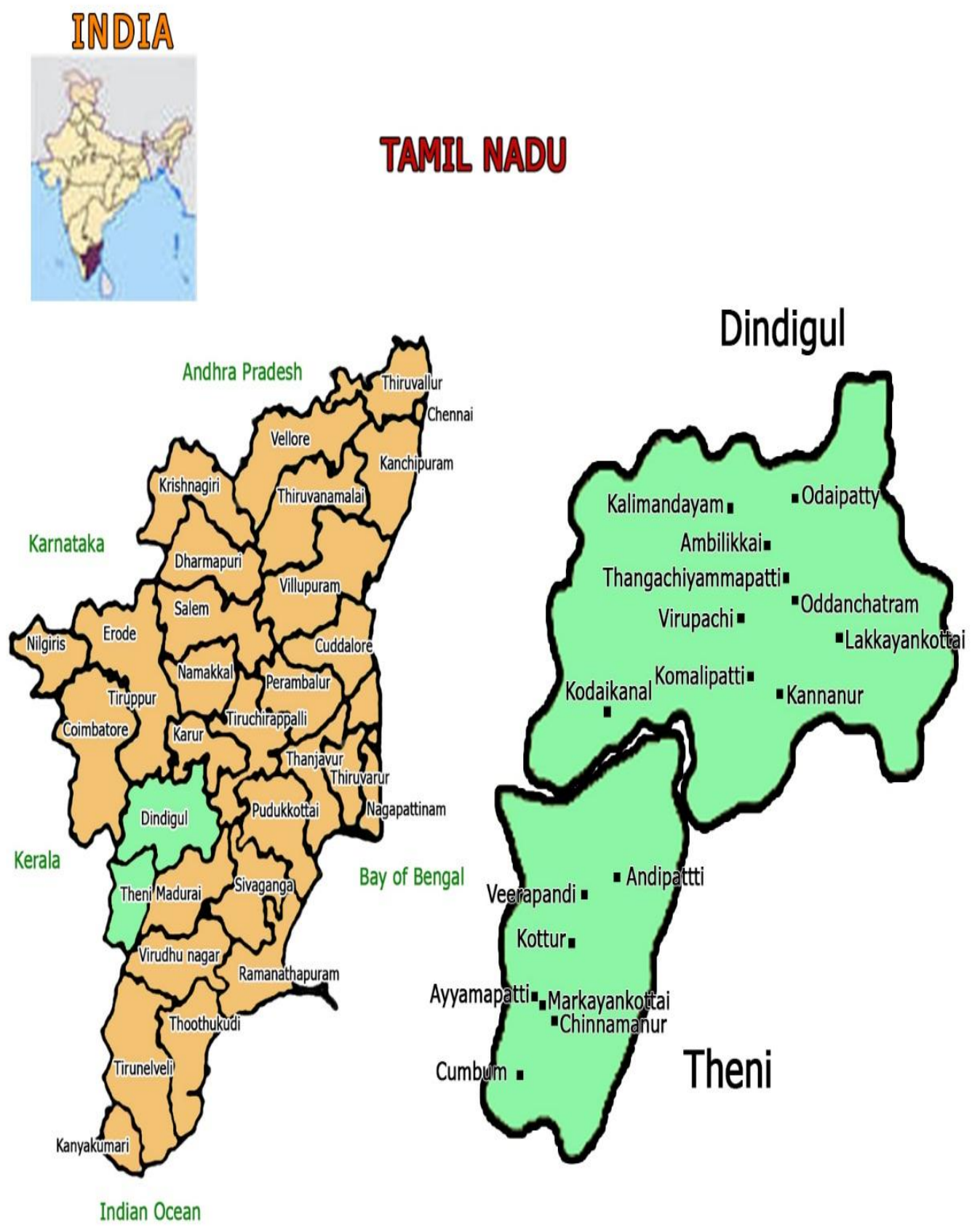



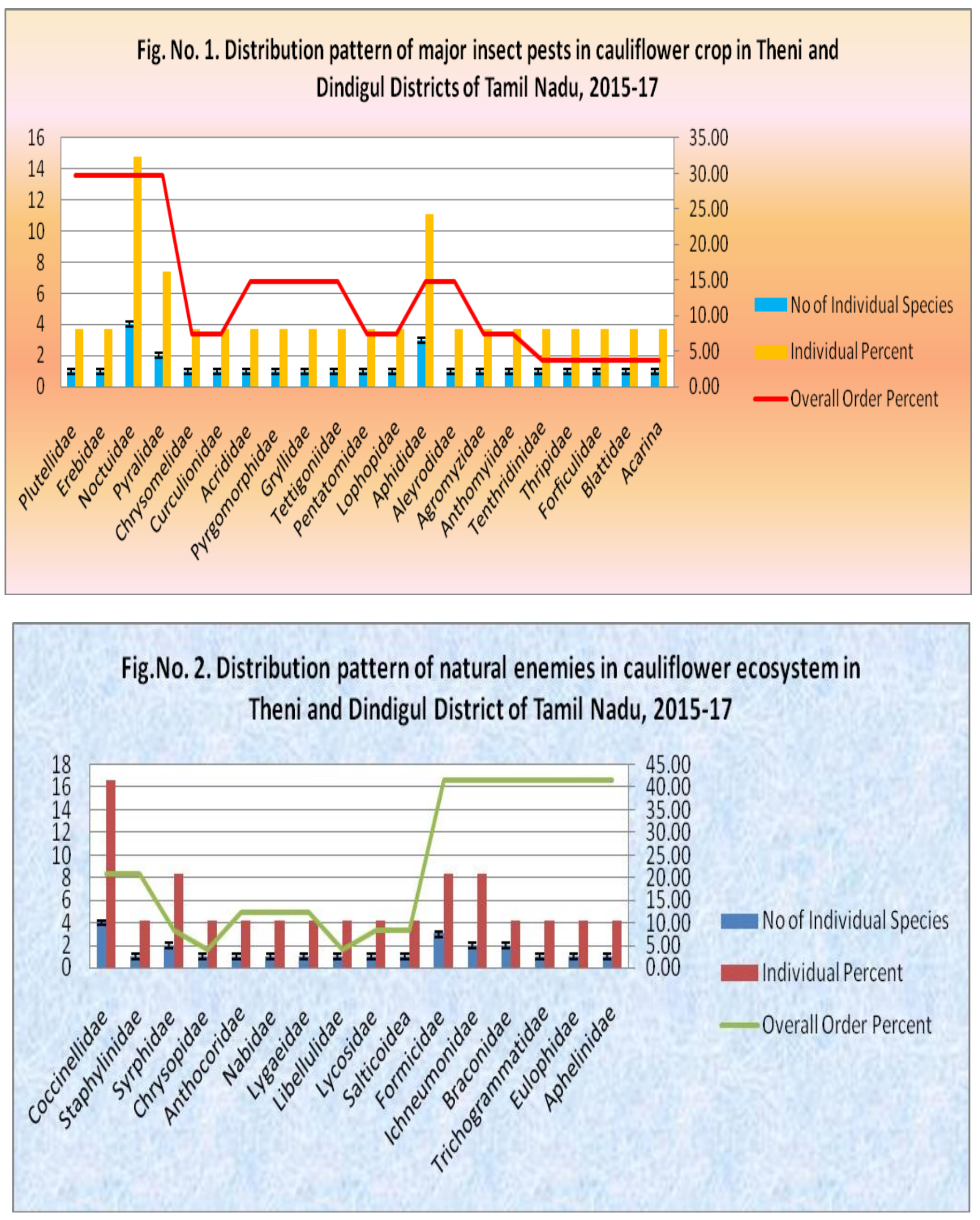
Table.1 Pests of cauliflower recorded during survey conducted at Theni and Dindigul districts, Tamil Nadu, 2015-2017

\begin{tabular}{|c|c|c|c|c|c|}
\hline $\begin{array}{l}\text { Sl. } \\
\text { No. }\end{array}$ & Common name & Scientific name & Order & Family & Destructive stage \\
\hline \multicolumn{6}{|c|}{ Biting and Chewing Insect pests: } \\
\hline 1. & Diamondback moth & Plutellaxylostella(L.) & Lepidoptera & Plutellidae & Caterpillar \\
\hline 2. & Tobacco caterpillar & Spodopturalitura(F.) & Lepidoptera & Noctuidae & Caterpillar \\
\hline 3. & Cutworm & Agrotisipsylon(Hub.) & Lepidoptera & Noctuidae & Caterpillar \\
\hline 4. & Cabbagesemilooper & Trichoplusiani (F.) & Lepidoptera & Noctuidae & Caterpillar \\
\hline 5. & Gram caterpillar & Helicoverpaarmigera(Hub.) & Lepidoptera & Noctuidae & Caterpillar \\
\hline 6. & Cabbage leaf webber & Crocidolomiabinotalis(Zell.) & Lepidoptera & Pyralidae & Caterpillar \\
\hline 7. & Head borer & Helullaundalis $(\mathrm{F})$. & Lepidoptera & Pyralidae & Caterpillar \\
\hline 8. & Bihar hairy caterpillar & Spilosomaobliqua(Wlk.) & Lepidoptera & Erebidae & Caterpillar \\
\hline 9. & Flea beetle & Phyllotreatacruciferae(Go.) & Coleoptera & Chrysomelidae & Adult \\
\hline 10. & Weevil & Myllocerusspp & Coleoptera & Curculionidae & Adult \\
\hline 11. & Shorthorned grasshoper & Oxyaspp & Orthoptera & Acrididae & Nymph and adult \\
\hline 12. & Grasshopper & Atractomorphacrenulata $(\mathrm{F})$. & Orthoptera & Pyrgomorphidae & Nymph and adult \\
\hline 13. & Katydids & Pterophillacamellifolia $(\mathrm{F})$. & Orthoptera & Tettigoniidae & Nymph and adult \\
\hline 14. & Cricket & Grylluscampestris(L.) & Orthoptera & Gryllidae & Nymph and adult \\
\hline 15. & Earwigs & Forbiculaauricularia (L.) & Dermaptera & Forficulidae & Adult \\
\hline 16. & Cabbage root borer & Delia radicum $(\mathrm{L})$. & Diptera & Anthomyiidae & Maggot \\
\hline 17. & Mustard sawfly & Athalialugensproxima(K1.) & Hymenoptera & Tenthredinidae & Larva \\
\hline 18. & Cockroach & Periplanetaamericana $(\mathrm{L})$. & Dictyoptera & Blattidae & Adult \\
\hline \multicolumn{6}{|c|}{ Sucking insect pest: } \\
\hline 19. & Painted bug & Bagradacruciferarum (Kirk.) & Hemiptera & Pentatomidae & Nymph and adult \\
\hline 20. & White fly & Bemisiatabaci (Genna.) & Homoptera & Aleyrodidae & Nymph and adult \\
\hline 21. & Aphid & Myzuspersicae(Sulzer) & Homoptera & Aphididae & Nymph and adult \\
\hline 22. & Aphids & Brevicorynebrassicae(L.) & Homoptera & Aphididae & Nymph and adult \\
\hline 23. & Mustard aphid & Lipaphiserysimi(Kalt.) & Homoptera & Aphididae & Nymph and adult \\
\hline 24. & Pyrilla & Pyrillaperpusilla (Wlk.) & Hemiptera & Lophopidae & Nymph and adult \\
\hline 25. & Mites & Unknown & Acarina & Unknown & Nymph and adult \\
\hline 26. & Thrips & Thripstabaci (Lindeman) & Thysanoptera & Thripidae & Nymph and adult \\
\hline 27. & Leaf miner & Chromatomyiahorticola $(\mathrm{G})$. & Diptera & Agromyzidae & Maggot \\
\hline
\end{tabular}


Table.2 Natural enemies of cauliflower recorded during survey conducted at Theni and Dindigul districts, Tamil Nadu, 2015-2017

\begin{tabular}{|c|c|c|c|c|c|c|c|}
\hline \multicolumn{8}{|c|}{ Predators: } \\
\hline $\begin{array}{l}\text { S. } \\
\text { No. }\end{array}$ & Common name & Scientific name & Family & \multicolumn{2}{|c|}{ Order } & \multicolumn{2}{|r|}{ Prey } \\
\hline 1. & Ground skimmer & Diplacodestrivialis(Ram.) & Libulellidae, & \multicolumn{2}{|c|}{ Odonata } & \multicolumn{2}{|c|}{ Diamondback moth } \\
\hline 2. & Syrphids & Episyrphusbalteatus(F.) & Syrphidae & \multicolumn{2}{|c|}{ Diptera } & \multicolumn{2}{|c|}{ Aphids and whitefly } \\
\hline 3. & Syrphids & Ischiodonscutellaris(F.) & Syrphidae & \multicolumn{2}{|c|}{ Diptera } & \multicolumn{2}{|c|}{ Aphids and whitefly } \\
\hline 4. & Coccinelids & Menochilussexmaculatus(F.) & Coccinellidae & \multicolumn{2}{|c|}{ Coleoptera } & \multicolumn{2}{|c|}{ Aphids and whitefly } \\
\hline 5. & Coccinelids & Brumoidessuturalis(F.) & Coccinellidae & \multicolumn{2}{|c|}{ Coleoptera } & \multicolumn{2}{|c|}{ Aphids and whitefly } \\
\hline 6. & Coccinelids & Coccinellatransversalis(F.) & Coccinellidae & \multicolumn{2}{|c|}{ Coleoptera } & \multicolumn{2}{|c|}{ Aphids and whitefly } \\
\hline 7. & Coccinelids & Scymnusspp & Coccinellidae & \multicolumn{2}{|c|}{ Coleoptera } & \multicolumn{2}{|c|}{ Aphids and whitefly } \\
\hline 8. & Rove beetle & Paederussp(F.) & Staphylinidae & \multicolumn{2}{|c|}{ Coleoptera } & \multicolumn{2}{|c|}{ Multiple } \\
\hline 9. & Green lace wings & Chrysoperlazastrowi(Sill.) & Chrysopidae & \multicolumn{2}{|c|}{ Neuroptera } & \multicolumn{2}{|c|}{ Aphids and whitefly } \\
\hline 10. & Pirates bugs & Oriusinsidiodus (Say) & Anthocoridae & \multicolumn{2}{|c|}{ Heteroptera } & \multicolumn{2}{|c|}{ Aphids and whitefly } \\
\hline 11. & Big eye bug & Geocorisspp (Say) & Lygaeidae & \multicolumn{2}{|c|}{ Heteroptera } & \multicolumn{2}{|c|}{ Aphids and whitefly } \\
\hline 12. & Damsel bug & Nabisspp (Reuter) & Nabidae & \multicolumn{2}{|c|}{ Heteroptera } & \multicolumn{2}{|c|}{ Small insect } \\
\hline 13. & Ants & Pheidolessp (Westwood) & Formicidae & \multicolumn{2}{|c|}{ Hymenoptera } & \multicolumn{2}{|c|}{ Diamondback moth } \\
\hline 14. & Carpenter Ants & Componotusspp (Latreille) & Formicidae & \multicolumn{2}{|c|}{ Hymenoptera } & \multicolumn{2}{|c|}{ Diamondback moth } \\
\hline 15. & Fire ant & Dorylusorientalis(Westw.) & Formicidae & Hyme & ptera & $\begin{array}{l}\text { Diams } \\
\text { Cotesi }\end{array}$ & back moth and \\
\hline 16. & Jumping spider & Unknown & Salticidae & Arane & & Multi] & \\
\hline 17. & Wolf Spider & Unknown & Lycosidae & Arane & & Multi] & \\
\hline Para & itoids: & & & & & & \\
\hline $\begin{array}{c}\text { S. } \\
\text { No. }\end{array}$ & Common name & Scientific name & Fam & & & rder & Parasitic stage \\
\hline 18. & Braconid wasp & Cotesiaplutellae(Kurdj.) & Braconidae & & Hym & loptera & Larval \\
\hline 19. & Ichneumon wasp & Diadegmasemiclausum(Kurdj.) & Ichneumoni & & Hym & ioptera & Larval \\
\hline 20. & Ichneumon wasp & Diadromusspp(Gravenhorst) & Ichneumoni & & Hym & ioptera & Larval -pupal \\
\hline 21. & Eulophid wasp & Oomyzussokolowski (Kurdj.) & Eulophidae & & Hym & ioptera & Larval -pupal \\
\hline 22. & Trichogramma & Trichogrammaspp & Trichogram & atidae & Hym & ioptera & Egg \\
\hline 23. & Parasitoid wasp & Encarsiaformosa(Gahan) & Aphelinidae & & Hym & optera & Nymph-adult \\
\hline 24. & Parasitoid wasp & Diareatiellaspp (M'Intosh) & Braconidae & & Hym & optera & Nymphs-Adult \\
\hline
\end{tabular}


Table.3 Distribution pattern of major insect pests of cauliflower ecosystems in Theni and Dindigul Districts of Tamil Nadu, India, 2015-17

\begin{tabular}{|l|l|l|l|l|l|}
\hline S. No & \multicolumn{1}{|c|}{ Order } & \multicolumn{1}{|c|}{ Family } & No. of species & \multicolumn{1}{|c|}{ Districts } & \multicolumn{1}{|c|}{ Elevations (above MSL) } \\
\hline 1. & Lepidoptera & Plutellidae & 01 & Dindigul and Theni & 150,500 and $1500 \mathrm{~m}$ \\
\hline 2. & Lepidoptera & Erebidae & 01 & Theni & $150 \mathrm{~m}$ \\
\hline 3. & Lepidoptera & Noctuidae & 04 & Dindigul and Theni & 150,500 and $1500 \mathrm{~m}$ \\
\hline 4. & Lepidoptera & Pyralidae & 02 & Dindigul and Theni & 150,500 and $1500 \mathrm{~m}$ \\
\hline 5. & Coleoptera & Chrysomelidae & 01 & Dindigul and Theni & 150 and $500 \mathrm{~m}$ \\
\hline 6. & Coleoptera & Curculionidae & 01 & Dindigul & 150 and $500 \mathrm{~m}$ \\
\hline 7. & Orthoptera & Acrididae & 01 & Dindigul and Theni & 150 and $500 \mathrm{~m}$ \\
\hline 8. & Orthoptera & Pyrgomorphidae & 01 & Dindigul & 150 and $500 \mathrm{~m}$ \\
\hline 9. & Orthoptera & Gryllidae & 01 & Dindigul & 150 and $500 \mathrm{~m}$ \\
\hline 10. & Orthoptera & Tettigoniidae & 01 & Theni and Dindigul & 150 and $500 \mathrm{~m}$ \\
\hline 11. & Heteroptera & Pentatomidae & 01 & Dindigul and Theni & 150,500 and $1500 \mathrm{~m}$ \\
\hline 12. & Hemiptera & Lophopidae & 01 & Dindigul & 150 and $500 \mathrm{~m}$ \\
\hline 13. & Homoptera & Aphididae & 03 & Dindigul and Theni & 150,500 and $1500 \mathrm{~m}$ \\
\hline 14. & Homoptera & Aleyrodidae & 01 & Dindigul and Theni & 150,500 and $1500 \mathrm{~m}$ \\
\hline 15. & Diptera & Agromyzidae & 01 & Dindigul and Theni & 150,500 and $1500 \mathrm{~m}$ \\
\hline 16. & Diptera & Anthomyiidae & 01 & Theni & 150 m \\
\hline 17. & Hymenoptera & Tenthredinidae & 01 & Theni & $150 \mathrm{~m}$ \\
\hline 18. & Thysanoptera & Thripidae & 01 & Dindigul & 150 and $500 \mathrm{~m}$ \\
\hline 19. & Dermaptera & Forficulidae & 01 & Dindigul & 150 and $500 \mathrm{~m}$ \\
\hline 20. & Dictyoptera & Blattidae & 01 & Dindigul and Theni & 150 and $500 \mathrm{~m}$ \\
\hline 21. & Acarina & Unknown & 01 & Theni & $150 \mathrm{~m}$ \\
\hline
\end{tabular}

Table.4 Distribution pattern of natural enemies of cauliflower ecosystems in Theni and Dindigul Districts of Tamil Nadu, India, 2015-17

\begin{tabular}{|l|l|l|l|l|l|}
\hline S. No & \multicolumn{1}{|c|}{ Order } & \multicolumn{1}{|c|}{ Family } & No. of species & \multicolumn{1}{c|}{ Districts } & Elevations (above MSL) \\
\hline 1. & Coleoptera & Coccinellidae & 04 & Dindigul and Theni & $150 \mathrm{~m}$ and $500 \mathrm{~m}$ \\
\hline 2. & Coleoptera & Staphylinidae & 01 & Dindigul and Theni & $150 \mathrm{~m}$ and $500 \mathrm{~m}$ \\
\hline & Diptera & Syrphidae & 02 & Dindigul and Theni & $150 \mathrm{~m}$ and $500 \mathrm{~m}$ \\
\hline 3. & Neuroptera & Chrysopidae & 01 & Theni and Dindigul & $150 \mathrm{~m}$ and $500 \mathrm{~m}$ \\
\hline 4. & Hemiptera & Anthocoridae & 01 & TheniandDindigul & $150 \mathrm{~m}$ and $500 \mathrm{~m}$ \\
\hline 5. & Hemiptera & Nabidae & 01 & Theni and Dindigul & $150 \mathrm{~m}$ and $500 \mathrm{~m}$ \\
\hline 6. & Hemiptera & Lygaeidae & 01 & Theni and Dindigul & $150 \mathrm{~m}$ and $500 \mathrm{~m}$ \\
\hline 7. & Odonata & Libellulidae & 01 & Dindigul and Theni & 150 and $500 \mathrm{~m}$ \\
\hline 8. & Araneae & Lycosidae & 01 & Dindigul and Theni & $150 \mathrm{~m}$ and $500 \mathrm{~m}$ \\
\hline 9. & Araneae & Salticidae & 01 & Dindigul and Theni & $150 \mathrm{~m}$ and $500 \mathrm{~m}$ \\
\hline 10. & Hymenoptera & Formicidae & 03 & Dindigul and Theni & 150 and $500 \mathrm{~m}$ \\
\hline 11. & Hymenoptera & Ichneumonidae & 02 & Dindigul and Theni & $150 \mathrm{~m}$ and $500 \mathrm{~m}$ \\
\hline 12. & Hymenoptera & Braconidae & 02 & Dindigul and Theni & $150 \mathrm{~m}$ and $500 \mathrm{~m}$ \\
\hline 13. & Hymenoptera & Trichogrammatidae & 01 & Dindigul and Theni & 150 and $500 \mathrm{~m}$ \\
\hline 14. & Hymenoptera & Eulophidae & 01 & Dindigul and Theni & 150 and $500 \mathrm{~m}$ \\
\hline 15. & Hymenoptera & Aphelinidae & 01 & Dindigul and Theni & 150 and $500 \mathrm{~m}$ \\
\hline
\end{tabular}


Table.5 Distributions pattern of major insect pests of cauliflower ecosystem based on plant part Damaged in Theni and Dindigul districts, Tamil Nadu during, 2015-17

\begin{tabular}{|c|c|c|c|c|}
\hline S. No. & $\begin{array}{c}\text { Plant parts damaged and } \\
\text { nature of damaged }\end{array}$ & $\begin{array}{l}\text { No. of } \\
\text { species }\end{array}$ & Species & $\begin{array}{l}\text { Diversity } \\
\text { per cent }\end{array}$ \\
\hline 1. & $\begin{array}{l}\text { Curds bites and feeds on } \\
\text { curd }\end{array}$ & 08 & $\begin{array}{l}\text { Plutellaxylostella(L.),Hellulaundalis(F.), } \\
\text { Spodopturalitura }(\mathrm{F} .), \text { Helicoverpaarmigera }(\mathrm{H}), \\
\text { Lipaphiserysimi } \\
(\text { Kalt.),Forbiculaauricularia(L.),Periplanetaamerica } \\
\text { na(L.), Myzuspersicae(Sul.) }\end{array}$ & 27.59 \\
\hline 2. & Stem and Cutting at base & 01 & Agrotisipsylon(Hubner) & 3.45 \\
\hline 3. & Leaves and Defoliates & 04 & $\begin{array}{l}\text { Spodopturalitura(F.), } \\
\text { Crocidolomiabinotalis(Z.),Athalialugensproxima(Klu } \\
\text { g), Myllocerusspp, Trichoplusiani(Fabricius), }\end{array}$ & 13.79 \\
\hline 4. & $\begin{array}{l}\text { Leaves, silvering, curling } \\
\text { and yellowing of leaves }\end{array}$ & 07 & $\begin{array}{l}\text { Thripstabaci(Lind.),Bagradacruciferarum(Kirk.),Bre } \\
\text { vicorynebrassicae(L.),Myzuspersicae(Sulzer), } \\
\text { Lipaphiserysimi(Kalt.),Pyrillaperpusilla (Wlk.), } \\
\text { Mites }\end{array}$ & 24.14 \\
\hline 5. & $\begin{array}{l}\text { Leaves, Webbing and } \\
\text { papery appearance }\end{array}$ & 01 & Crocidolomiabinotalis (Zeller) & 3.45 \\
\hline 6. & Leaves zigzag leaf mines & 01 & Phytomyzahorticola (Goureau) & 3.45 \\
\hline 7. & Roots and stem, rottening & 01 & Delia radicum(Linnaeus) & 3.45 \\
\hline 8. & Stem and curd by boring & 01 & Hellulaundalis (Fabricius) & 3.45 \\
\hline 9. & $\begin{array}{llll}\text { Leaf mining or circular } \\
\text { hole }\end{array}$ & 01 & Plutellaxylostella(Linnaeus) & 3.45 \\
\hline 10. & $\begin{array}{lll}\text { Leaves circular minute } \\
\text { holes }\end{array}$ & 01 & Phyllotretacruciferae (Goeze) & 3.45 \\
\hline 11. & Leaves, marginal feeding & 03 & Grasshopper, katydids, cricket & 10.34 \\
\hline \multicolumn{2}{|l|}{ Total } & 29 & & 100 \\
\hline
\end{tabular}


In conclusion, the most widely distributed and prevalent orders of insects infesting cauliflower crop in Theni and Dindigul District noticed during the survey were Lepidoptera, Hemiptera, Orthoptera, Coleoptera, Diptera, Dermaptera, Dictyoptera, Thysanoptera, Hymenoptera and Acarina. The most successful natural enemies noticed during above mentioned districts were under the insect orders of Hymenoptera, Coleoptera, Diptera, Odonata, Neuroptera, Hemiptera and Araneae.

\section{Acknowledgement}

The first author is thankful to ICAR, India for providing the Senior Research Fellowship during the experiment. The authors are thankful to the farmers of Theni and Dindigul Districts for sparing their fields and manpower and to execute the survey during the year 2015-2017.

\section{References}

Agarwal, V. M., Rastogi, N., Raju, S. V. S. 2007. Impact of predatory ants on two lepidopteran insect pests in Indian cauliflower agroecosystems. J. Appl. Entomol., 131: 493-500.

Anil, S., 2004. Studies on seasonal population fluctuations of aphid pests of cabbage and their predators.Pest Management in Horticultural Ecosystems, 10(1): 41-48.

Anita, Singh and Suchi, Gandhi. 2012. Agricultural insect pest: Occurrence and infestation level of agricultural fields of Vadodara, Gujarat. International Journal of Scientific Research and Publications, 2(4): 1- 5.

Bhatia, R., and Verma, A. K. 1993. Insect pests' complex of cabbage in Himachal Pradesh. J. Insect Sciences, 6(2): 297298.

Bonnemaison, L., 1965. Insect pests of crucifers and their control. Annual Review of Entomol, 10: 233-256.
Chandramohan, N., 1994.Seasonal incidence of diamondback moth, Plutella xylostella (Linn.) and its parasitoids in Nilgiris. J. Biol. Cont., 8: 77-80.

Chaudhuri, N., Ghosh, S. and Senapati, S. K. 2001. Incidence of insect pests of cabbage in relation to prevailing climate conditions of Terai regions. Indian $J$. Entomol., 63(4): 421-428.

Chen, L.L., Kuang, M. Z., Zhen, Z. D., Cao, Y., and $\mathrm{Xu}, \mathrm{W}$. W. 1987. A survey of natural enemies of insect pests of vegetable crops in the suburbs of Guangzhou. pp. 393-399 in Fan, H.Z. (Ed.) Integrated control of insect pests and diseases in vegetable crops. Guangzhou, Guangzhou Science Technology Press (in Chinese).

Deeplata, S., and Rao, D. V. 2012. A field study of pest of cauliflower, cabbage and okra in some areas of Jaipur. Int. J. Life science Botanical and Pharm. Res., 1(2): 122-127.

Firake, D. M., Lytan, D., and Behre, G. T. 2012. Biodiversity and seasonal activity of arthropod fauna in Brassicaceus crop ecosystems of Meghalaya, North-east India. Molecular Entomol, 3(4): 18-22.

Haseeb, M., Kobori, Y., Amano, H. and Nemoto, H. 2001. Population density of Plutella xylostella (Lepidoptera: Plutellidae) and its Parasitoid Cotesiaplutellae (Hymenoptera: Braconidae) on two varieties of cabbage in an urban Environment. Applied Entomology and Zoology, 36(3): 353360.

Indian Horticulture Database, 2015.National Horticulture Board, Ministry of Agriculture, Govt. of India.www.nhb.gov.in.

Jalali, S. K., Singh, S. P. and Venkatesan, T. 2003. Life table characteristics of Trichogramma toideabactrae Nagaraja at different temperatures on eggs of Plutella xylostella (Linn.). Pest 
Management in Horticultural Ecosystems, 9(1): 13-17.

Lal, O.P., 1975. A compendium of insect pest of vegetables in India. Bull.Entomol. Res., 56: 16-31.

Lu, Y.X., 1983. A preliminary survey of natural enemies of larvae of Plutella xylostella. Natural Enemies of Insects, 5: 188-189.

Palande, P. R., Pokharkar, D. S., and Nalawade, P. S. 2004. Seasonal incidence of cabbage pests in relation to weather. Pest Management in Horticulture Ecosystems, 10(2): 151156.

Raja, M., William, S. J. and David, B. V. 2014. Population dynamics of key insect pests of cabbage in Tamil Nadu. Indian J. Entomol., 76(1): 01-07.

Ratnasri, M., 2012. Survey and management of defoliator pests of cabbage. M. Sc, Theses, University of Agricultural Sciences, Dharwad, pp-49.

Sachan, J. N., and Gangwar, S. K. 1990. Seasonal incidence of insect pests of cabbage, cauliflower and knolkhol. Indian J. Entomol., 52: 111-124.
Sachan, J. N., and Srivastava, B. P. 1972. Studies on seasonal incidence of insect pests of cabbage. Indian J. Entomol., 34: 123-129.

Sarfraz, M., Andrew, B. K. and Lioyd, M. D. 2005. Biological control of diamondback moth, Plutella xylostella: A review. Biological Science and Technology, 15: 763-789.

Singh, R. P., and Pal, S. 2014. Insect pest diversity in cauliflower and its relation to abiotic factors. Ann. of Plant Protec. Sci.,22:291-295.

Ushachauhan, Bhalla, O. P. and Sharma, K. C. 1997. Biology and seasonality of the diamondback moth, Plutella xylostella (Lepidoptera: Yponomeutidae) and its parasitoids on cabbage and cauliflower. Pest Management in Horticultural Ecosystems, 3(1): 7-12.

Wu, J.W., Wang, J. R., Wang, J., Shi, B. D., Wang, W., Wang, B. Z. Dong, Z. H. Wei, D. Z., and Huang, Q. F. 1987. A list of natural enemies of insect pests of vegetable crops in Beijing. Acta Agricultura Boriali-Sinica, 2: 75-96.

\section{How to cite this article:}

Arun Debbarma, J. Jayaraj, P. Chandramani, N. Senthil, M. Ananthan and Prabakaran, K. 2017. A Survey on Occurrence and Diversity of Insect Pests of Cauliflower in Dindigul and Theni Districts of Tamil Nadu, India. Int.J.Curr.Microbiol.App.Sci. 6(9): 2495-2505. doi: https://doi.org/10.20546/ijcmas.2017.609.307 